\title{
ENERGY POLICY IN THE ACTUAL CONTEXT OF FOREIGN POLICY
}

\author{
Ionelia Bianca BOSOANCĂ \\ M.A. Student, Faculty of European Studies, \\ Babeș-Bolyai University, Cluj-Napoca, Romania \\ bianca.bosoanca@gmail.com
}

\begin{abstract}
According to the problems that European Union is facing with, the incidents that marked the European continent and the spreading of the fear among citizens, is related to the identification of the causes of terrorism. European Union attempts to make citizens believe in European values and not be afraid that it will be unable to provide them security. Eurosceptics are now in favor of criticizing strongly the values that the Europe promotes, arguing that this building did not take into account many of the safety' aspects, economic cooperation and did not create a common identity for Member States. Pro-Europeans argue that the only way to protect citizens, is cooperation between countries. Those perspectives are based on the sustainability of the Energy Union and are reflected on the European policies aimed in energy and environmental security. Based on the fact that researchers are analyzing the reports and the European institutions, we can outline that energy policy and environmental safety can be shaped on three paths of this namely the setback, the stagnation and the progress. In this context where an important role is played by Russia - a geostrategic actor of the scheme of energy supply- the question is how will succeed European Union to pass over these difficulties? Will Russia continue to be the energetic power of the European system or will European Union succeed in resolving the problem of dependency of European states on Russia?
\end{abstract}

Keywords: Energy Policy, governance process, actors, European values, cooperation.

\section{Introduction}

The present paper argues upon the necessity of developing a sustainable energy policy for the states of the European Union which will help European states to succeed in 
resolving the problem of dependency on Russia. Despite the fact that Russia will continue to be the energetic power of the European system, European Union has the necessary instruments to fight for its survival. Discussing the tree scenarios of the energy union developing and analyzing the scientists work, it will be taken into consideration the most optimistic and possible scenario - the assembling of a European Energy Union - with the purpose of convince European states to cooperate.

Energy policy subject was established on the agenda of the European Union. However, it has become a topic of concern for specialists only in the context in which Russia began to restrict the natural gas distribution for countries that were dependent on imports of Russian gas, trying to use energy supplies as a tool of foreign affairs. At the legislative level, the document which has emphasized the need for an energy policy for states of the European Union and emphasized the importance of ensuring energy security was the Lisbon Treaty, adopted in 2009. Energy policy has its origins in the Treaty of Rome, in 1957, with the assembling of the European Atomic Energy Community and later recognized by the Single European Act in 1986 and the Maastricht Treaty in 1992. The goal of putting together the financial resources and the economic implications was the reason for diminishing the interest in energy policy at European level and was the source of ignoring the negative consequences of the extensive energy resources imports.

In the context of economic growth of Russia, interconnected energy market will improve the development of cooperation among states. Transeuropean networks will be a good solution for European states to pass over this crisis. The European documents defined three types of innovation projects proposed for the energy sector improvement, such as: projects of common interest, projects of European's interest and priority projects. Transeuropean energy networks have proposed a significant number of specific objectives through the development of projects of European common interest to the neighboring countries in the energy field, creating intelligent transport networks. However, these 
networks must be checked by the criteria of efficiency and safety in their operation process in order to develop a functional system of delivering energy within the borders of Europe.

The importance of a European self-help state mechanism is given by the threat that Russia exets on countries because the European states can not supply themselves with energy needs. In the context of actual controversial European foreign policy with Russia, the major objective of European Union is to develop a functional structure which can offer stability from the point of energy citizens' needs. The main purpose of European Union is to put all the European states together and make them to cooperate. At this level, European Energy Union policy will need a multi-level governance which involve all actors that can bring a significant contribution to strengthening the Energy Union. Moreover, this union will not remain only at the stage of a formal project, which can not be implemented in the field. Each actor will contribute with its resources to ensure the functionality of this project and will transform the overall goal into specific objectives that can be applied in each state. The European Commission will be the head of this concept, because this legal structure will play the most important and most difficult role, which is to oversee European countries and will sanction the states for engagements and deadlines it were not respected. The states will be responsible for supporting the European Commission's strategy.

In addition to these responsibilities, the European Commission should provide support and advice the states in the enforcement related issues. The challenge remains to offer its ongoing strategic support for issues that will appear at the supranational level but also at national level, where countries will seek help in solving the problems the states are facing with. In terms of innovation, the Commission will have to find new alternative technologies to provide solutions for transmission of energy to fulfill its purpose for which they were created and will make the needed changes in today's world, in the context of technological advance.

We can say that innovation was the element that contributed to regional development by stimulating the economy and making specific choices for each region of 
the Europe. In this regard with the development it is said that community and cooperative projects have changed energy generation in many European countries and have significantly contributed to revitalising the local economy, to create jobs and regional value will increase in terms of development of the region.

We believe that through scenarios concerning the evolution enery union will succeed in achieving the goal of cooperation among states to ensure stocks of energy where Europe will face a crisis of resources and thus will reduce dependence on powerful actor, Russia. Energy Union is a complex project of the European Union, which requires major investments and efforts from European countries, but whose results will be seen in the medium and long term and will be able to ensure energy security and also will protect the planet from emissions carbon dioxide. Energy Union results will not be seen in the range of a few months, but the analysis predict that their effect will be positive for the future of the Europe.

The development of recent EU energy policy has been made within the context of: a trend of increasing energy import dependence (from 50 percent of total EU energy consumption in 2007 to a forecast of 65 percent in 2030) (European Commission, 2007); increasing prices (quintupling of oil prices between 2002 and 2010); EU enlargement and historical relations with Russia/USSR and, relatively higher energy import dependence; gas supply disruptions. As a result, energy security as defined by the EU has been undermined, and a policy window opened which the European Commission attempted to exploit. (Maltby, 2013, p. 1)

At the global level, we are facing with a series of climate changes, influenced by the activities that human nature has caused with the scorn of the danger that the environment has been exposed. Scientists have warned about global warming, which increases from one year to another, advancing the working groups of the EU institutions, reports and statistics on phenomena that occur in the world. The climate changes problem can affect biodiversity and environmental safety and can destroy the natural habitat. For 
this reason, the European Institutions need to accord particular importance of preventing the environment when they will develop European Energy' policies.

\section{Strategic objectives of the European Union}

The issue of European policy on energy security of the states of the Central and Eastern Europe, in the context of natural resources depletion and climate change occurring in the world, is a relevant issue for researchers. The goal of their research is to analyze factors that influence the current state of the European Union and which is the impact of changes that happened in the world and which are in a strong relation with the European policies. These results will be analyzed and will be developed in terms of new energy policies and environmental safety.

Monopolistic position that Russia has adopted on the European arena when it reduce the supply of natural gas for European states, was an important milestone in the history of energy policy. That was the moment when Central and Eastern Europe, in particular, need to find viable solutions to achieve Energy Union. Thus, European states put their problem now in terms of developing a package of measures on energy policy. And the solution is a better cooperation between the states and the final objective is to restrict the dependence of the states on the import of oil and gas resources, in particular of the Russian Federation resources and to return states to free market competition.

In regard with the energy and environmental security, the Commission desires to create a sustainable infrastructure development framework for allowing states to use alternative fuels. Renewable energy is a source of earning for European countries because this strategy attempts to reduce the dependence on the geostrategic actor - Russia - and also reduce the pollution of the Earth by using renewable energy in detriment of traditional ones. The strategy affirm that summarize the main points on energy, and comes up with concrete solutions. 
In the context of the review of the Security of Gas Supply Regulation, the Commission will also propose to ensure appropriate transparency of commercial gas supply contracts that may have an impact on EU energy security, while safeguarding the confidentiality of sensitive information. Despite progress made in recent years, Europe's energy system is still underperforming. The current market design does not lead to sufficient investments, market concentration establishing an information exchange mechanism with regard to intergovernmental agreements between Member States and third countries in the field of energy and weak competition remain an issue and the European energy landscape is still too fragmented. We have to give a new political boost to completing the internal energy market. The internal market's hardware: connecting markets through interconnections. At this moment, the European electricity and gas transmission systems, notably cross border connections, are not sufficient to make the internal energy market work properly and to link the remaining energy islands to the main electricity and gas network (European Commission, Energy Union Package, 2015, pp. 7 $8)$.

The Energy Union strategy has five mutually-reinforcing and closely interrelated dimensions designed to bring greater energy security, sustainability and competitiveness: energy security, solidarity and trust; a fully integrated European energy market; energy efficiency contributing to moderation of demand; decarbonising the economy and research, innovation and competitiveness (European Commission, 2015, p. 4). Among the objectives mentioned by the Commission in its strategic document, an important amount have the reports in which the major progress on energy policy has been analyzed. A progress must be checked by reports who emphasizes the effectiveness of energetic policies conducted in this area by the European Commission. Before the elaboration of a new policy, it is feasible to analyze energy policy measures used previously to develop a new strategy. Analyzing the previous policy strategy is extremely important to be sure that the objectives have been achieved, what objectives could not be achieved and which were the causes of 
their failure. All the reports will be analyzed based on the presumption that a measure of energy policy was or was not viable in terms of costs-benefits, and it can sustainable and be supported financially by the actors involved in drafting a public policy.

Another priority of the European Commission for the next period is the implementation of energy and climate package for 2030 (European Commission, 2015, p. 2) This document is extremely important due to its complexity, the details had made to clarify every aspect of each chapters with reference on energy and environmental safety, had given explanations to all problems that the energy sector is facing with, but also had proposed solutions.

The strategy of the European Union on energy policy and environmental safety is extremely optimistic and proposes a series of clear objectives aimed at both short-term results when we are talking about the end of 2020, and also long-term results with reference here to the goals you have for Europe of 2030. We can say that the strategy is extremely optimistic, if we look from the perspective of performance indicators when we estimate the percentage's reduction of $\mathrm{CO} 2$ emissions.

\section{Strategic pillars of the European Energy Policy}

The most important pillars of energy policy are internal energy market, energy security and climate change component. The pillar of internal energy market refers to a market liberalization of the European energy market where every competitor can access the market, either it is European or not. European Union seeks to achieve this liberalization of the internal market to eliminate the monopoly markets in which there is one actor who manipulate the market price, depending on the policy of creating its own price. From here arise the situations when companies which produce electricity or states which hold unique natural resources become a monopoly market, contributing to a dependence on other countries for resources or services that they distribute on the market. Energy market reform aims to boost competitiveness in the electricity market, eliminating the monopoly of 
overcharging products and services offered by the companies that have monopoly and eliminate anti-competitive practices provided by them. This process will be achieved through European legislation governing the internal energy market, both at the state level and at European level to ensure free access to the electricity networks, both public companies and private companies. To implement this legislation, DGs of the European Commission, Directorate General Competition General Directorate on Trade in question, will have to cooperate for the realization of this legislation and the legislative act on the internal energy market reform will be adopted by co-decision. To achieve this reform, in addition to the supranational and national institutions, an important role will be played by lobby agencies, which will come also with their own contribution to the development of this legislation, when it will be submitted to the European Commission consultation parties directly or indirectly involved in the process.

The second pillar is the energy security. This pillar aims to create stocks reserve of resources, which will be available for European countries, where they will face a deficit and will serve as a borrowing mechanism. This loan will be covered by other resources or the failure of a payment standard used in internal resources. This form of saving energy wants to create a pillar of inter-connectivity between European countries, to facilitate cooperation between them, in order to ensure the necessary resources for energy production or derived from traditional sources or from alternative sources. If in the past there was no question of ensuring energy security, now the argument that each country is able to produce its energy needs from its own resources should be taken into consideration. Global population growth calls into question the increased demand and increased production, but the danger of depletion occurs in this case, the dissolution of producing energy from traditional sources.

Europeans are aware that there may be a similarity between the situation in the Middle East and Europe, through the dependency of some European geostrategic actorRussia- holding monopoly in the market of natural gas resources, resources that are 
indispensable for some countries. Will Europe have the capacity to ensure its own production? There is no doubt about the fact that Russia has the freedom to determine the price for the production of gas that it exports of member states which are dependent on raw materials, because Russia holds supremacy and is a major player in the natural gas exports for the European states. The issue is not only on this sense but also because when they negotiate agreements with state, they are negotiated between the buyer and the Russian state. Countries with a historical tradition on the European arena, such as Italy, France or Germany, enjoy the privilege of having its own foreign policy when it comes to negotiate bilateral agreements with Moscow on Russian gas imports. Involving state actors such as governments and state companies that produce energy, but also a number of negotiators trained in this area, aimed at signing bilateral agreements favorable to the states for which the signatory of the agreement, obtaining a number of terms and conditions favorable for both parts. Bad agreements signed by European countries with Russia should not be a surprise for European Union, in the case of states where the percentage of resources provided from own sources are somewhere under the percentage of $30 \%$, in countries such as: Hungary, Bulgaria, Slovakia, or countries do not have their own natural gas resources, such as: Estonia, Latvia, Lithuania or Finland; countries that don't have a real prestige on the international arena, states economically weak and lacking of a prestigious geostrategic status. More than the position of inferiority that they have to other European countries, these countries do not have specialists in bilateral negotiations with Moscow.

Last, but not the least pillar of Energy Policy makes references to climate changes, changes which Planet will confront with over decades. European leaders want to convey the global message about the importance of protecting the environment and the impact that the human actions have on the environment and they want to create a series of mechanisms to stop or just to reduce the percentage of gaze emissions with sera effect. 
Issue no. 22/2017

\section{Future predictions}

Security of energy supply represents one of the priorities that the European Commission maintains for creating a single energy market. This is certainly thought in terms of developing trustable relationships between European partners - here we refer at the European states - a system in which the welfare of citizens is an important point, ensuring his well-being both on the economy and the environment side.

Energy Union is regarded by experts in the field to be one of the most ambitious targets that the European Commission has proposed to achieve for the energy policy and the environmental safety. Moreover, Energy Union is the key to success for the states of Central and Eastern Europe to reduce their dependency from the geostrategical actorRussia. Looking at the premises which the energy policy and environmental safety have, we find that the European Union is a successful mechanism because it brings positive results for European Commission's strategy.

Significant reliance on imports and a regulatory framework that does not encourage investment in the development of new resources or alternative sources of energy supply at reasonable prices can have negative consequences for the energy independence of a country and the cost of imports, that the balance of trade and payments (Iuga, 2014, p. 13). By this argument is stresses the importance of investment in energy, transport and in establishment of infrastructure for the supply of resources from other sources than Russian. Infrastructure is an important component for the states of the Central and Eastern Europe, because there are serious problems with the energy supply, especially for those states which have difficulties to ensure their own necessary. Moreover, infrastructures are the needed tool for reducing the states' dependence on Russian imports and it helps states to realize the interconnection of European energy markets. It is well known the fact that without strengthening the current infrastructure existing in European countries, will be difficult to achieve a proper Energy Union. And without a functional Energy Union, the European Commission's energetic strategy must be reconsidered. 
Radu Dudău comes to reinforce the idea that Energy Union intends to create infrastructure by reconsidering in new possibilities for interconnecting European states with countries such as Norway, Canada, USA, Algeria, Azerbaijan, Turkey Turkmenistan and countries in Africa or the Middle East, trying to find a strategic plan to facilitate the access to this states with the European energy market.

The political speeches between Ukraine and Russia triggered a real tension between Europe and Russia and for this reason, it is necessary for the European Union to interfere in this conflict. Ukrainian crisis has represented a crucial test for relations between Europe and Russia but also for Europe, who realized that the internal energy market does not assure stability and security, and it is time to take a stand. Moreover, the European Union has seen that it is placed in a vulnerable situation because of the insufficient resources that Europe has in its possession. That was the sign for European countries to find tools to reduce dependence on Moscow. And one of these tools was to create an Energy Union. Achieve this Energy Union it took a long series of discussions between stakeholders, to understand the necessity of achieving a European energy market through a communitarization the national policy debate waged between federalists and interguvernamentalists (Dudău, 2014, p. 3).

European energy policy on energy aims a functional internal market by creating a mechanism at European level to ensure market liberalization energy and security of energy supply. Moreover, it is necessary to transform the energy policy in a safer one, which is able to support states with energy supply. To achieve this goal it is required a support mechanisms which help internal market integration, investment in infrastructure and regulations on its functioning (Tangerås, 2013, p. 3).

In many EU Member States, national goals have translated into regional and local goals and strategies for the development of renewables. This could be regarded as a best practice example. The European Commission could encourage other Member States to 
make use of such instruments, for example by requiring administrations to include them in their national plans. (European Renewable Energies Federation, 2016, p. 20)

\section{Conclusions and recommendations}

The "Energy Union" can be seen as the most significant policy idea that seeks to reform European energy governance, policy and regional cooperation. It gives hope for solving the major paradox of EU energy policy - the inherent tension between national sovereignty over the energy sector and a community perspective based on solidarity, cooperation and scale. As such, it could help the EU energy policy overcome its 'cardinal sins' (Szulecki and Westphal, 2014, p. 14)

\section{References:}

- AJANOVIC A., et al. (2013), "Driving on renewables- on the prospects of alternative fuels up to 2050 from an energetic point-of-view in European Union countries", Journal of Energy Resources Technology, vol. 135, no. 3, pp. 31-201.

- DUDĂU, R., (2014) Energy security options of Romania Year 2014 and market projects of natural gas, EPG Analysis, April, pp.1-12, $\underline{\text { http://gpf- }}$ europe.com/upload/iblock/6e4/dudau_romanias-energy-security\%20options.pdf ((last accessed 15.11.16).

- EUROPEAN COMMISSION (2014), The Communication of the European Commission to the European Parliament and the Council - The European Strategy of Energetic Security, $\operatorname{COM}(2014)$ 330, Bruxelles, http://www.eesc.europa.eu/resources/docs/european-energysecurity-strategy.pdf, (last accessed 15.11.16).

- EUROPEAN COMMISSION (2015), Communication to the European Parliament, the Council, the European Economic and Social Commitee, the Commitee of the Regions and the European Investment Bank: A Framework Strategy for a Resilient Energy Union with a 
Forward-Looking Climate Change Policy, COM/2015/080 final, Bruxelles, http://eurlex.europa.eu/resource.html?uri=cellar:1bd46c90-bdd4-11e4-bbe101aa75ed71a1.0001.03/DOC_1\&format=PDF, (last accessed 20.11.16).

- EUROPEAN COMMISSION (2015), Commission Work Programme 2016, COM(2015) $610 \quad$ final, Strasbourg, 27.10.2015, https://ec.europa.eu/info/sites/info/files/cwp_2016_en_0.pdf, (last accessed 20.11.16).

- EUROPEAN RENEWABLE ENERGIES FEDERATION (2016), "EREF to public consultation on a new renewable energy directive for the period after 2020", Position Paper, February, pp. 1-43, http://www.eref-europe.org/download/1383/, (last accessed 20.11.16).

- IUGA, V. (2014), "Energy Sector in Romania: Actual provocations and solutions for the future", published in Dungaciu, Dan et al. (eds.), 7 teme fundamentale pentru România 2014, București, Ed. RAO, pp. 1-26, http://www.enpg.ro/shared/images/publicatii/84/6.\%20Capitol\%20energie_Vasile\%20Iuga \%202014_v2\%20final.pdf, (last accessed 19.11.16).

- KUSTOVA, I. (2015), "EU-Russia Energy Relations, EU Energy Integration, and Energy Security: the State of the Art and a Roadmap for Future Research", European Journal for European Research, vol. 11, no 3, pp. 288-295.

- MELNIKAS, B. (2015), "Innovation strategies for the European Union", Lithuanian Public Administration Training Association, vol. 1/2, no. 45/46, pp. 67-77.

- SZULECKI, Kacper et al. (2015), "Giving Shape to the Energy Union - Evolution, national expectations and implications for EU energy and climate governance", Working Paper prepared in relation to the conference: "The 2020 Strategy Experience: Lessons for Regional Cooperation, EU Governance and Investment”, Berlin, 17 June 2015, pp. 1-16, http://papers.ssrn.com/sol3/papers.cfm?abstract_id=2623892, (last accessed 20.11.16). 
- TANGERÅS, Th. (2013), "Renewable Electricity Policy and Market Integration, Research Institute of Industrial Economics", IFN Working Paper, no. 968, pp. 1-28, http://www.ifn.se/wfiles/wp/wp968.pdf, (last accessed 14.11.16). 